\title{
Innovative screening tests for COVID-19 in South Korea
}

\author{
Sangchun Choi', Chul Han², Jisook Lee', Sang-II Kim³ ${ }^{3}$ In Byung Kim ${ }^{4}$ \\ 'Department of Emergency Medicine, Ajou University School of Medicine, Suwon, Korea \\ ${ }^{2}$ Department of Emergency Medicine, Ewha Womans University, Shool of Medicine, Seoul, Korea \\ ${ }^{3}$ Department. of Oncology \& Hematology, H Plus Yangji General Hospital, Seoul, Korea \\ ${ }^{4}$ Department of Emergency Medicine, Myongji Medical Foundation Myongji Hospital, Goyang, Korea
}

Recently, the number of Corona Virus Disease 2019 (COVID-19) cases has increased remarkably in South Korea, so the triage clinics and emergency departments (ED) are expected to be overcrowded with patients with presumed infection. As of March 21st, there was a total of 8,799 confirmed cases of COVID-19 and 102 related deaths in South Korea that was one of the top countries with high incidence rates. ${ }^{1}$ This sharp increase in infection is associated with 1) outbreaks in individual provinces, 2) deployment of rapid and aggressive screening tests, 3) dedicated healthcare staffs for virus screening tests, 4) quarantine inspection data transparency and accurate data reporting, and 5) public health lessons from previous Severe Acute Respiratory Syndrome (SARS) and Middle East Respiratory Syndrome (MERS) outbreaks. This commentary introduces innovative screening tests that are currently used in South Korea for COVID-19, e.g., Drive-Through and Walk-Through tests, and compare the advantages and disadvantages of both methods.

Keywords Infectious Disease Outbreak, Virus Diseases, Early Detection of Disease, COVID-19 diagnostic testing

Drive-Through (DT) and Walk-Through (WT) tests are designed to provide a rapid screening, have a minimal risk of infection, and reduce excessive use of medical supplies like personal protective equipment (PPE). ${ }^{2}$ The risk of infection may be reduced by limiting the exposure of testees or direct contacts between the testees and healthcare workers. The DT tests are generally conducted in large low-traffic areas, such as public parking or stadium parking lots. ${ }^{2,3}$ On the other hand, the WT tests can be performed in a clean testing booth that can be installed near the hospital. Table 1 shows the pros and cons of DT and WT testing for COVID-19.

\section{DRIVE-THROUGH (DT) TESTING FOR COVID-19}

Testing for COVID-19 can be performed at a drive-through site, as shown in Fig. 1. The driver/ testee can stay inside his car during the entire process $(<15 \mathrm{~min})$, consisting of multiple steps: patient registration (3-4 min), medical examination ( $2 \mathrm{~min}$ ), specimen collection (2 min), discharge instructions ( $2 \mathrm{~min}$ ), and payment for testing service $(2 \mathrm{~min})$. Healthcare workers are supposed to wear the level-D PPE that is composed of inner and outer gloves, a gown (hooded coverall), an N95 mask (respirator), goggles (eye shield) or a face shield, and safety shoes or boots. Depending on the required contact level with patients or the availability of medical supply resources, healthcare staff may use PPE after modifying it, following the facility guidelines. ${ }^{4}$
Received: 31 March 2020

Revised: 8 April 2020

Accepted: 13 April 2020

Correspondence to: Sangchun Choi Department of Emergency Medicine, Ajou University School of Medicine, 164 Worldcup-ro Yeongtong-gu, Suwon 16499, Korea

E-mail: avenue59@ajou.ac.kr ORCID

https://orcid.org/0000-0003-2271-3434

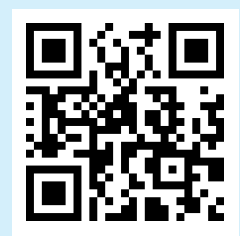

How to cite this article:

Choi S, Han C, Lee J, Kim SI, Kim IB. Innovative Screening Tests for COVID-19 in South Korea. Clin Exp Emerg Med 2020;7(2):73-77.

This is an Open Access article distributed under the terms of the Creative Commons Attribution Non-Commercial License (https:// creativecommons.org/licenses/by-nc/4.0/). 
Table 1. Pros and cons of Drive-through (DT) and Walk-through (WT) test for COVID-19

\begin{tabular}{|c|c|c|c|}
\hline & \multirow{2}{*}{ DT testing } & \multicolumn{2}{|l|}{ WT testing } \\
\hline & & Negative pressure booth type & Positive pressure booth type \\
\hline Pros & $\begin{array}{l}\text { - Efficiency } \\
\text { - Testing can be completed within } 15 \text { min. } \\
\text { - Privacy protection } \\
\text { - The testee remains in his/her car during the entire process. } \\
\text { - Reduced risk of infection } \\
\text { - Tests are conducted outdoors. } \\
\text { - The car provides isolation to the testee. } \\
\text { - No additional equipment } \\
\text { - There is no need for an extra isolation room or negative } \\
\text { pressure room. }\end{array}$ & $\begin{array}{l}\text { - Efficiency } \\
\text { - Testing can be completed in about } 20 \text { min. } \\
\text { - Reduced risk of infection } \\
\text { - Disinfection and ventilation of the booth should } \\
\text { be done after every use, and it can be done with } \\
\text { relative ease. } \\
\text { - Healthcare staffs don't make any direct contact } \\
\text { with the testees. } \\
\text { - Prevent excessive use of medical supplies } \\
\text { - The booth walls separate healthcare staff from } \\
\text { testees, so the use of medical supplies is reduced. } \\
\text { - Reduced workload } \\
\text { - The workload for conducting the WT tests is less } \\
\text { than the DT tests. } \\
\text { - Robustness of method } \\
\text { - The booth is installed close or next to the hospital } \\
\text { unit, so testing is less likely to be affected by } \\
\text { adverse weather conditions. } \\
\text { - Test more patients } \\
\text { - Testing service is accessible even to non-drivers. } \\
\text { - It is possible to test multiple patients at once using } \\
\text { more than one clean booth. }\end{array}$ & $\begin{array}{l}\text { - Efficiency } \\
\text { - Testing can be completed in about } \\
15 \text { min. } \\
\text { - Reduced risk of infection } \\
\text { - No need for disinfection and ventila- } \\
\text { tion of the booth } \\
\text { - Healthcare staffs don't make any } \\
\text { direct contact with the testees. } \\
\text { - Prevent excessive use of medical } \\
\text { supplies } \\
\text { - The booth walls separate healthcare } \\
\text { staff from testees, so the use of } \\
\text { medical supplies is reduced. } \\
\text { - Reduced workload } \\
\text { - The workload for conducting the WT } \\
\text { tests is less than the DT test. } \\
\text { - Test more patients } \\
\text { - Testing service is accessible even to } \\
\text { non-drivers. } \\
\text { - It is possible to test multiple patients } \\
\text { at once using more than one clean } \\
\text { booth. }\end{array}$ \\
\hline Cons & $\begin{array}{l}\text { - Medical consumerism } \\
\text { - A patient may get tested at multiple testing sites, which can } \\
\text { be seen as promoting medical consumerism. } \\
\text { - Additionally required supports } \\
\text { - Healthcare staffs will benefit from a support person who helps } \\
\text { with writing orders and filling out medical records. } \\
\text { - The testing site should be in the areas that are less populated } \\
\text { but close enough to the hospital for future follow-up. } \\
\text { - Worker fatigue } \\
\text { - Healthcare staff fatigue due to excessive workload. Working } \\
\text { outdoors }>2 \text { hours wearing the high-level PPE can tire the } \\
\text { staff to the level of fatigue, so taking frequent breaks is } \\
\text { recommended. } \\
\text { - Risk of infection } \\
\text { - The risk of infection exists related to possible handling } \\
\text { errors of samples. } \\
\text { - Healthcare staff may lose attention when changing gowns or } \\
\text { gloves due to fatigue. } \\
\text { - Testing capacity limitations } \\
\text { - Non-drivers cannot use the testing service. } \\
\text { - Cross-infection may occur between the driver and the } \\
\text { passenger, so only one person/driver at a time should be } \\
\text { tested per vehicle. } \\
\text { - Adverse weather conditions } \\
\text { - Adverse weather conditions may complicate outdoors testing. } \\
\text { - Cost } \\
\text { - The initial cost of the installation of a test site can be } \\
\text { relatively high. }\end{array}$ & $\begin{array}{l}\text { - Medical consumerism } \\
\text { - A patient may get tested at multiple testing sites, } \\
\text { which can be seen as promoting medical consum- } \\
\text { - Risk of infection } \\
\text { - The risk of infection exists for the testees while } \\
\text { he/she is waiting for the test in a reception area, } \\
\text { especially if overcrowded. } \\
\text { - The risk of infection exists for healthcare staff for } \\
\text { any kind of equipment failures, such as glove tears } \\
\text { or perforation. }\end{array}$ & $\begin{array}{l}\text { - Medical consumerism } \\
\text { - A patient may get tested at multiple } \\
\text { testing sites, which can be seen as } \\
\text { promoting medical consumerism. } \\
\text { - Risk of infection } \\
\text { - The risk of infection exists for } \\
\text { healthcare staff for any equipment } \\
\text { failure, such as when the gloves tear. } \\
\text { - Adverse weather conditions } \\
\text { - Adverse weather conditions may } \\
\text { complicate outdoors testing. }\end{array}$ \\
\hline
\end{tabular}




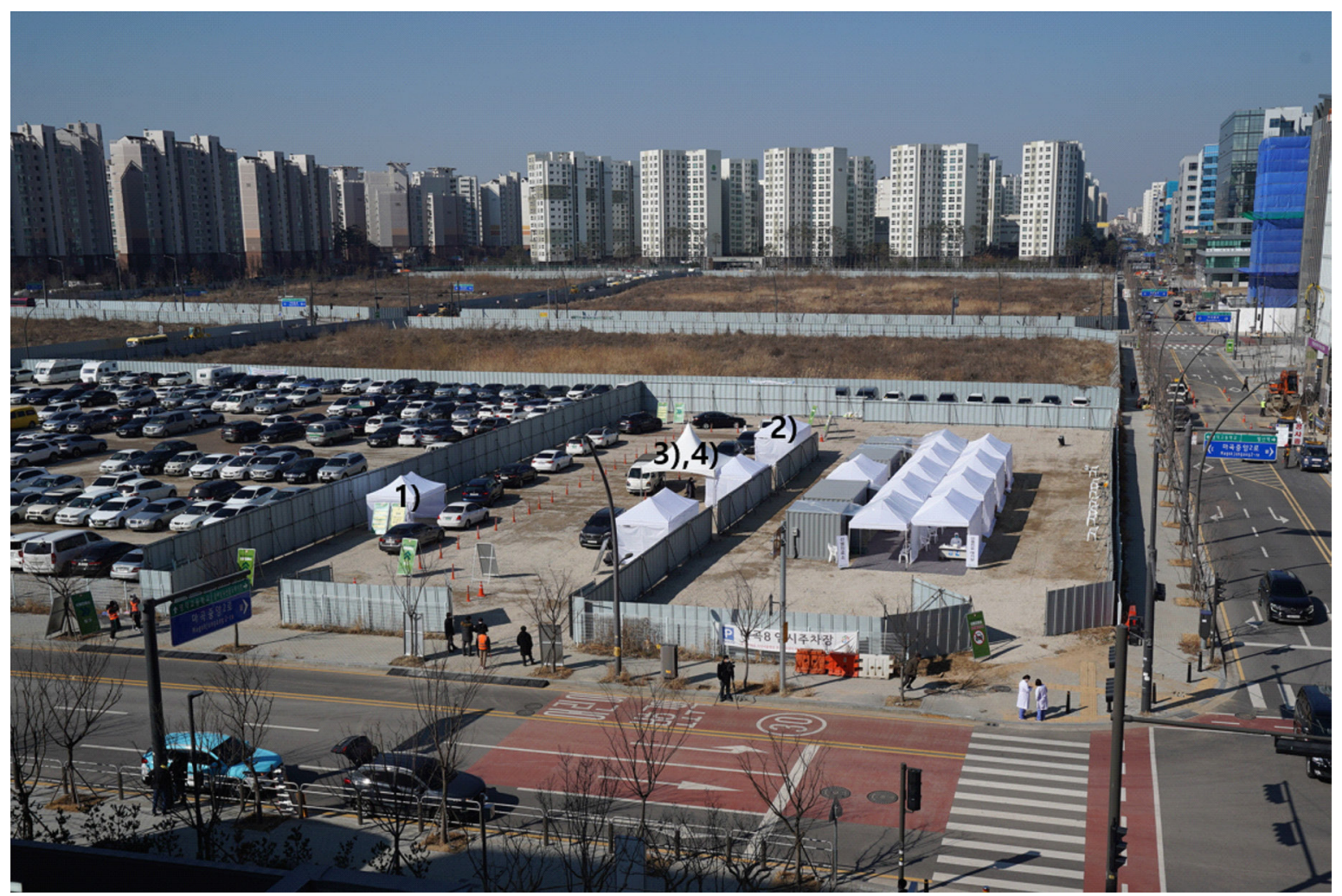

Fig. 1. The Drive-through (DT) testing site.

1) Registration: Healthcare staff assists the check-in process.

2) Medical exam: Healthcare staff records testee's symptoms, personal information, and epidemiologic association. The staff completes this process using a mobile phone without making contact with the testee. If the testee is suspected of coronavirus infection, his/her samples are collected before he/she gets transferred to a designated hospital.

3) Collection of specimens: Healthcare staff leans over the open window for naso- and oro-pharyngeal swabs, and then the testee closes his/her car windows to collect his/her sputum specimen. Car ventilation is set at the "recirculation" mode to minimize the risk of infection for healthcare workers. After receiving the samples, the healthcare staff puts on a new vinyl apron and disinfects his/her hands using alcohol-based hand sanitizer.

4) Discharge instructions: The testee gets the information about how to check the test result and is asked to self-quarantine until further notice regarding the outcome. Instructions are also provided regarding what the testee should do if his/her symptoms get worse.

\section{WALK-THROUGH (WT) TESTING FOR COVID-19}

Testing for COVID-19 can be performed at a walking-through site, as shown in Fig. 2.

\section{Negative pressure booth}

In the WT test using a negative pressure booth, the testee stays inside the disinfected booth, while the healthcare worker is outside the booth, disallowing a direct contact between the two. The clean booth is designed to enclose the testee with transparent walls and a pair of gloves on one wall for healthcare staff to use when collecting patient samples and examining the patient. Before the test, healthcare staff is required to put on the PPE consisting of a pair of gloves, a gown, and a disposable face mask.
The PPE can be adjusted to follow the facility guidelines or according to the availability of medical supply resources. The whole testing process, from registration to payment, can be completed in about 20 minutes.

\section{Positive pressure booth}

The WT test using a positive pressure booth combines the advantages of the DT test and the WT test using a negative pressure booth. The tester stays inside the booth while the testee stays outside; thus, direct contact between the two is avoided (Fig. 3). The positive pressure booth looks similar to the negative pressure booth. Positive pressure inside the booth is used to prevent contaminants from coming inside the booth. The testing process is similar but shorter $(<10 \mathrm{~min})$ since it is unnecessary to disinfect the booth after each test. 

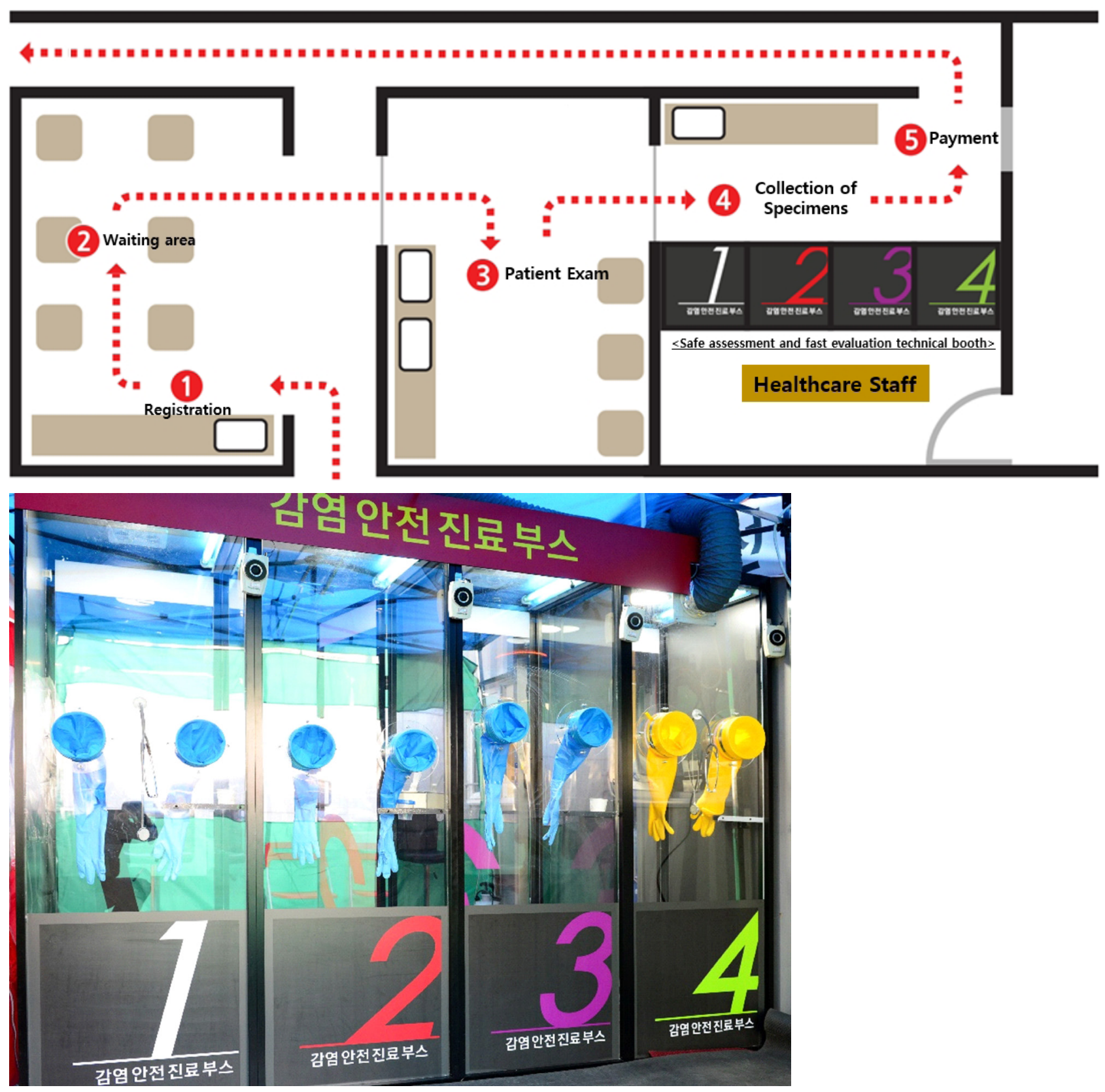

Fig. 2. The Walk-through (WT) test using the negative pressure booth. (Top) Flow diagram of the testing, and (Bottom) a picture of four "safe assessment and fast evaluation technical booths."

1 \& 2) Patient registration and waiting in the reception area: A one-stop kiosk assists the check-in process, reducing the risk of infection for both the healthcare staff and the testee.

3) Patient exam: Healthcare staff records testee's symptoms, personal information, and epidemiologic association. The staff can complete this process using a mobile phone or a Personal Computer (PC) system.

4) Collection of specimens and discharge instructions: The testee enters the clean booth once the check-in process is complete. The testee stays inside the negative pressure booth, while the healthcare staff is outside the booth the whole time. The booth was designed with transparent walls, one of which has a pair of long gloves for a healthcare worker to use to make naso- and oro-pharyngeal swabs. The testee collects the sputum sample by himself/herself in the closed booth. The testee then receives information about how to check the test result and how to self-quarantine. Instructions are also provided regarding what the testee should do if his/her symptoms get worse. After the exit of the testee, the booth gets ventilated and disinfected for 2 minutes the first time and 10 minutes after that. 


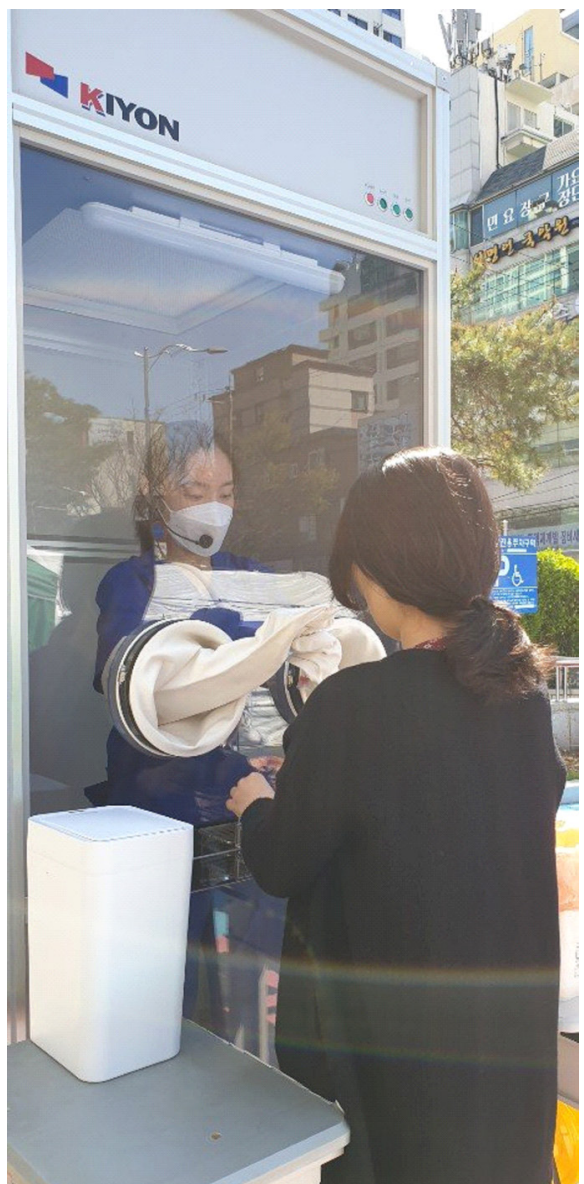

Fig. 3. The Walk-through (WT) test using the positive pressure booth. ${ }^{7}$

1) Medical exam: Healthcare staff records testee's symptoms, personal information, and epidemiologic association. The booth is installed in a tent or a container house separated from the hospital. The staff can complete this process using a mobile phone without making contact with the testees. If the testee is suspected of coronavirus infection, his/her samples are collected before he/she gets transferred to a designated hospital.

2) Collection of specimens: The tester enters into the positive pressure booth and stays inside, while the testee is outside. The booth is designed with transparent walls, one of which has a pair of long gloves for a healthcare worker to use to make naso- and oro-pharyngeal swabs. The testee collects the sputum sample by himself/herself outside the booth.

3) Discharge instructions: The testee receives the information about how to check the testing result and is asked to self-quarantine until further notice regarding the outcome. Instructions are also provided regarding what the testee should do if his/her symptoms get worse.
Pandemics caused by viruses have tended to break out once every decade or every other decade over the past 300 years. ${ }^{5}$ Now, they may be occurring more often and in more variable cycles. Successful management of viral infection and diseases requires quarantine and treatment of those who may have an infection. Thus, early-stage screening tests that are efficient and effective are essential for preventing the virus from spreading widely. Each step of the testing process should be completed quickly and minimize the existing risk of infection for healthcare workers and testees alike, meeting the general safety requirements.

In this commentary, we introduce innovative screening testing that has been successfully applied to the COVID-19 outbreak in South Korea. Although the efficacy of the methods should be further clarified, we believe that our experience with a successful implementation of these tests for COVID-19 may apply to other countries.

\section{REFERENCES}

1. Korean Centers for Disease Control and Prevention. Current statistics of COVID-19 in Korea. http://ncov.mohw.go.kr/bdBoardList_Real.do?brdld $=1 \&$ brdGubun $=13 \&$ ncvContSeq $=$ \&contS eq $=\&$ board_id $=\&$ gubun $=$. Updated 2020. Accessed March 21, 2020.

2. Weiss EA, Ngo J, Gilbert GH, Quinn JV. Drive-through medicine: a novel proposal for rapid evaluation of patients during an influenza pandemic. Ann Emerg Med 2010;55:268-73.

3. Kwon KT, Ko JH, Shin H, Sung M, Kim JY. Drive-Through Screening Center for COVID-19: a Safe and Efficient Screening System against Massive Community Outbreak. measures. J Korean Med Sci 2020;35:e123.

4. World Health Organization. Rational use of personal protective equipment for coronavirus disease 2019 (COVID-19). Interim guiance 27 February 2020. https://apps.who.int/iris/bitstream/handle/10665/331215/WHO-2019-nCov-IPCPPE_use2020.1-eng.pdf. Updated 2020. Accessed March 21, 2020.

5. Gust ID, Hampson AW, Lavanchy D. Planning for the next pandemic of influenza. Rev Med Virol 2001;11:59-70.

6. Radonovich $\sqcup J r$, Cheng J, Shenal BV, Hodgson M, Bender BS. Respirator tolerance in health care workers. JAMA 2009;301(1): 36-8.

7. Song B. Evolving COVID-19 Sampling... 'Super-speed Walking Through Test' Came Out [Internet]. Joongang Ilbo; 2020 [cited 2020 Mar 31]. Available from: https://news.joins.com/article/ 23743568. 